\title{
THE PREVALENCE, IMPACT AND MANAGEMENT OF URINARY INCONTINENCE IN THE FEMALE POPULATION OF THE USA
}

\author{
Dr. EBOO VERSI \\ MA DPhil (Oxon) MB BChir (Cantab) MRCOG \\ CLINICAL ASSOCIATE PROFESSOR, DEPT OB. GYN., \\ UNIVERSITY MEDICAL AND DENTAL SCHOOL OF NEW JERSEY, USA
}

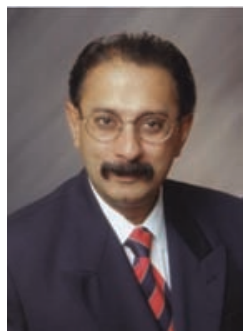

\section{Dr. RON COREY}

$P h D, M B A, R P h$ - ADJUNCT FACULTY, PHILADELPHIA COLLEGE OF PHARMACY, UNIVERSITY OF THE SCIENCES IN PHILADELPHIA, PHILADELPHIA, PENNSYLVANIA, USA

\begin{abstract}
Dr Versi is Global Medical Director in Urology and Women's Health at Pharmacia Corporation and Associate Professor in Obstetrics, Gynecology and Reproductive Sciences at UMDNJ-Robert Wood Johnson Medical School. He currently sits on the expert advisory panel in urogynecology for FIGO, WHO: International Consultation on Incontinence, and ad hoc committees for the NIH. Until 1999 he was Associate Professor in Obstetrics, Gynecology and Reproductive Biology at Harvard Medical School and Chief of Urogynecology, a division he set up at the Brigham and Women's Hospital, six years' ago. Prior to leaving academia, he was Chairman of the Research Committee of the American Urogynecologic Society. In the United Kingdom, Dr Versi received his BA, MA and PhD degrees from St Peter's College, University of Oxford, and a MD degree from Kings College, University of Cambridge. He completed a residency in obstetrics and gynecology and a fellowship in urogynecology in 1987 at Kings College Hospital in London, UK. He is a member of the Royal College of Obstetricians and Gynecologists. Dr Versi belongs to many international and national professional societies and has published about 100 database peer review articles, books, book chapters, and letters to learned journals.
\end{abstract}

Il Dr. Versi è Direttore Medico in Urologia e Salute femminile presso la Pharmacia Corporation e Professore Associato di Ostetricia, Ginecologia e Scienze della Riproduzione presso la UMDNJ-Robert Wood Johnson Medical School. Attualmente fa parte del gruppo consultivo di esperti di uroginecologia della FIGO, OMS: Consulenza Internazionale sulla Incontinenza, e in comitati ad hoc per i NIH. Fino al 1999 è stato Professore Associato di Ostetricia, Ginecologia e Biologia della Riproduzione presso la Harvard Medical School e Primario di Uroginecologia, una divisione che aveva costituito sei anni prima presso il Brigham and Women s Hospital. Prima di lasciare il mondo accademico, è stato Presidente del Comitato per la Ricerca della Società di Uroginecologia Americana. Negli Stati Uniti, il Dr. Versi, ha conseguito i titoli di BA, MA e PhD presso il St Peter s College, all'Università di Oxford, e un titolo di MD presso il Kings College, Università di Cambridge. Ha ottenuto la specializzazione in ostetricia e ginecologia e una borsa di studio per la ricerca in uroginecologia nel 1987 presso il Kings College Hospital di Londra nel Regno Unito. Ė membro del Royal College of Obstetricians and Gynecologists. Il Dr. Versi fa parte di numerose associazioni professionali internazionali e nazionali e ha pubblicato circa 100 articoli per database peer review, libri, capitoli di libri e lettere a riviste specialistiche. 
Urinary incontinence is estimated to affect up to $30 \%$ of women in the USA, although differences in the populations studied and the definition of urinary incontinence have contributed to wide variations in estimates of its prevalence. The number of women with overactive bladder (characterised by symptoms of urinary frequency and urgency with or without urge incontinence) is likely to be even higher. Although bladder symptoms are relatively common and have a significant negative impact on their quality of life, many women fail to seek treatment, believing that their symptoms are a consequence of aging or childbirth. Instead, they may adopt complex coping strategies, such as the use of protective pads. Behavioral techniques, such as Kegel exercises and bladder training are useful first-line treatments for stress and urge incontinence, respectively. In addition, women with urge incontinence as well as symptoms of frequency and urgency may also be treated successfully with an antimuscarinic agent, such as tolterodine (Detrol LA $® /$ Detrusitol SR ${ }^{\circledR}$ ). Public education programs to raise awareness about urinary incontinence and its treatment aim to improve communication between physician and patient to ensure that bladder symptoms are recognised and treated appropriately.
Secondo le ultime stime, l'incontinenza urinaria che colpisce le donne degli Stati Uniti d'America raggiunge il $30 \%$, anche se le differenze rilevate nelle popolazioni studiate e la definizione di incontinenza urinaria hanno contribuito ad espandere le variazioni nelle stime di tale diffusione. E' molto probabile, però, che il numero di donne che possiede un'iperattività vescicale (caratterizzata dai sintomi di urgenza e frequenza urinaria che si associano o meno all'incontinenza da urgenza) diventi sempre maggiore. Sebbene i sintomi che riguardano la vescica siano relativamente comuni e abbiano un significativo impatto negativo sulla qualità della vita, numerose donne non richiedono alcun trattamento, nella convinzione che i loro sintomi siano conseguenza dell'invecchiamento o del parto. Molte donne, invece, ad adottare complessi metodi di contenimento personali, come l'utilizzo di tamponi protettivi. Le tecniche comportamentali, come gli esercizi di Kegel e il Training della vescica risultano trattamenti utili e fondamentali rispettivamente per l'incontinenza da urgenza o da stress. In aggiunta, le donne che presentano un'incontinenza da urgenza o sintomi di urgenza e frequenza possono ricevere un trattamento dagli esiti positivi utilizzando un agente antimuscarinico, come ad esempio la tolterodina (Detrol LA ${ }^{\circledR} /$ Detrusitol SR ${ }^{\circledR}$ ). I programmi pubblici di istruzione nei riguardi dell'IU e del relativo trattamento hanno come obiettivo il miglioramento della comunicazione tra medico e paziente per un trattamento appropriato dei sintomi vescicali. 


\section{INTRODUCTION}

Bladder symptoms and urinary incontinence may affect up to one-third of women in the USA. Although most epidemiological studies have focused on women who experience involuntary loss of urine, there is increasing recognition that overactive bladder $(\mathrm{OAB})$, which is characterized by symptoms of urinary frequency and urgency, with or without urge incontinence, is also widespread among women. Regardless of the nature and cause of their symptoms, many women do not seek treatment for their bladder symptoms, either due to embarrassment or because they believe that urinary incontinence is an inevitable consequence of childbirth or aging. In addition, many patients and their families are not aware that effective treatments are available. This article reviews the prevalence and treatment of urinary incontinence and $\mathrm{OAB}$ in women in the USA, and considers the importance of public education programs in ensuring that patients receive the most appropriate treatments for these distressing symptoms.

\section{DEFINING URINARY INCONTINENCE}

Before considering the prevalence of urinary incontinence among women in the USA, it is necessary to define exactly what is meant by urinary incontinence. The International Continence Society (ICS) defines it as 'a condition where involuntary loss of urine is a social or hygienic problem

\section{INTRODUZIONE}

I sintomi relativi alla vescica e l'incontinenza urinaria colpiscono fino a un terzo delle donne negli USA. Sebbene la maggior parte degli studi epidemiologici si siano concentrati sulla popolazione femminile che subisce una perdita involontaria di urina, esiste un progressivo riconoscimento del fatto che anche l'iperattività vescicale (OAB), caratterizzata da sintomi di urgenza e frequenza urinaria, associati o meno a incontinenza da urgenza, è largamente diffusa. Incuranti della natura e delle cause dei loro sintomi, molte donne non richiedono un trattamento per i sintomi vescicali, o per l'imbarazzo o per la convinzione che l'incontinenza urinaria sia una conseguenza inevitabile del parto o dell'invecchiamento. Numerose pazienti e i loro familiari, inoltre, non sono a conoscenza del fatto che sono oggi disponibili trattamenti efficaci. Questo articolo riesamina la diffusione e il trattamento dell'incontinenza urinaria e il fenomeno OAB nelle donne negli USA e considera l'importanza dei programmi pubblici di istruzione nel garantire ai pazienti i trattamenti più appropriati per questi fastidiosi sintomi.

\section{DEFINIZIONE DELL'INCONTINENZA URINARIA}

Prima di considerare la diffusione dell'incontinenza urinaria tra le donne negli USA, è necessario definire esattamente cosa si intende per incontinenza urinaria. L'International Continence Society (ICS) la definisce come "una condizione nella quale la perdita di urina rappresenta un problema sociale 
and is objectively demonstrable' [1]. This broad definition encompasses several different manifestations, including the two most common forms of urinary incontinence: stress incontinence and urge incontinence. In stress incontinence, there is involuntary loss of urine associated with increased intra-abdominal pressure (e.g. when coughing, sneezing, laughing or lifting heavy objects), which is due to failure of the urethral sphincter. Urge incontinence is the involuntary loss of urine associated with a strong desire to void (urgency). Many patients have mixed incontinence (i.e. symptoms of both stress and urge incontinence) [1]. However, there is increasing recognition that many women suffer from the condition of $\mathrm{OAB}$, in which there are involuntary contractions of the detrusor muscle during the storage phase of the micturition cycle. These contractions give rise to symptoms of urinary frequency ( $\geq 8 / 24$ hours), urgency (a strong desire to void), with or without urge incontinence (urine loss if the desire to void cannot be suppressed) [1], and may also cause nocturia (waking more than once at night to urinate). The natural history of $\mathrm{OAB}$ is not fully understood, but it has been suggested that symptoms of frequency and urgency may progress to symptoms of urge incontinence. e igienico che è oggettivamente dimostrabile" [1]. Questa ampia definizione racchiude numerose manifestazioni differenti, incluse le due più comuni forme di incontinenza urinaria: da stress e da urgenza. Nell'incontinenza da stress si verifica una involontaria perdita di urina associata a una maggiore pressione addominale (i.e. quando si tossisce, si starnutisce, si ride e si sollevano oggetti pesanti), dovuta a un malfunzionamento dello sfintere uretrale. L'incontinenza da urgenza risulta una perdita involontaria di urina associata a un forte desiderio di mingere (urgenza). Molti pazienti soffrono di un'incontinenza mista (i.e. sintomi di entrambe le incontinenze) [1]. Tuttavia, si sta verificando un progressivo riconoscimento relativo al fatto che numerose donne soffrono della condizione di OAB, nella quale si assiste a contrazioni involontarie del muscolo detrusore durante la fase di accumulo del ciclo di minzione. Queste contrazioni fanno insorgere sintomi di frequenza urinaria ( $>=8 / 10$ ore), di urgenza (un forte desiderio di mingere), associati o meno a incontinenza da urgenza (perdita di urina se il desiderio di evacuare non può essere represso). Lo sviluppo naturale del fenomeno $\mathrm{OAB}$ non è stato completamente compreso, ma è stata suggerita l'ipotesi secondo la quale i sintomi di frequenza e urgenza possono progredire fino a trasformarsi in sintomi di incontinenza da urgenza. 


\section{PREVALENCE OF BLADDER SYMPTOMS}

The prevalence of bladder symptoms in the population is hard to define and reported estimates vary greatly. The reasons for the disparity are numerous: there is no unifying definition for urinary incontinence or for $\mathrm{OAB}$ and the ICS definitions of incontinence or $\mathrm{OAB}$ are not specific enough for prevalence investigations. Therefore, the outcomes of existing prevalence studies are affected by the definition of severity or type of incontinence [2]. For example, a study that measures the prevalence of incontinence based on only one symptom (e.g. level of urine leakage) is likely to report a different prevalence rate than a study that distinguishes between the various types of incontinence. In addition, many prevalence studies have been based upon questionnaire surveys that have not been validated using objective clinical assessments [1, 2]. This is particularly important as the questionnaires should have low sensitivity (to identify all potential patients) and high specificity (in terms of definitions of bladder symptoms). For example, in a meta-analysis of epidemiological studies of urinary incontinence, Hampel and colleagues [1] found that, although almost all surveys asked specific questions to identify stress incontinence, only about half of the studies included questions specifically designed to identify urge incontinence.

The issues surrounding prevalence estimates extend to the measurement of $\mathrm{OAB}$ also. The majority of studies carried out have investigated only in-

\section{DIFFUSIONE DEI SINTOMI RELATIVI ALLA VESCICA}

La diffusione dei sintomi relativi alla vescica tra la popolazione è difficile da definire e le stime fornite differiscono in maniera significativa. Le ragioni per cui si verifica questa disparità sono numerose: non esiste una definizione unificante per l'incontinenza urinaria o per il fenomeno OAB e le definizioni dell'ICS relative all'incontinenza e all'OAB non sono abbastanza specifiche per analisi sulla diffusione. Per tale motivo i risultati di studi sulla diffusione esistente vengono influenzati dalla definizione di gravità o tipo di incontinenza [2]. Ad esempio, è possibile che uno studio volto a misurare la diffusione dell'incontinenza basandosi soltanto su un sintomo (i.e. livello di perdita di urina) riporti un grado differente di diffusione rispetto a uno studio che opera una distinzione tra i vari tipi di incontinenza. In aggiunta, numerosi studi sulla diffusione sono stati basati su indagini tramite questionario che non sono state convalidate da una valutazione clinica oggettiva [1, 2]. Ciò risulta particolarmente importante nel caso in cui il questionario debba possedere un basso indice di gravità (per identificare tutti i potenziali pazienti) e un'alta specificità (in termini di definizioni dei sintomi relativi alla vescica). In una meta-analisi di studi epidemiologici sull'incontinenza urinaria, ad esempio, Hampel e collaboratori [1] hanno evidenziato che, anche se quasi tutte le indagini riportavano domande specifiche per l'individuazione dell'incontinenza da stress, solo un numero pari a circa la metà degli studi includeva domande intese ad identificare l'in- 
continence, and have not taken into account the symptoms of frequency and urgency, even though about half of those with OAB do not present with urge incontinence [3]. No validated OAB-specific questionnaires have been developed with which to investigate the prevalence of OAB.

For these reasons, it has been recommended by specialists at the first International Consultation on Incontinence that the measurement instruments for bladder symptoms in community surveys should be standardized for worldwide use [2].

Overall, approximately 13 million people in the USA are thought to suffer from urinary incontinence, with prevalence being greater in women than in men [2]. Estimates suggest that the prevalence of urinary incontinence in women may be as high as $30 \%$. For example, one survey of 541 healthy women aged between 42 and 50 years in Pittsburgh found that 58\% had experienced involuntary loss of urine at some time, while 31\% had regular episodes of incontinence, with at least one episode per month [4]. In general, the prevalence of incontinence increases with age (Table 1) and with childbirth [5].

A review of 21 studies found that in women with urinary incontinence, an estimated $49 \%$ had stress incontinence, $29 \%$ mixed incontinence and $22 \%$ urge incontinence [1].

Prevalence estimates for OAB range from 17 million to 71 million in the USA [9]. This means that, even at the lower end of the range, $\mathrm{OAB}$ is more prevalent than diabetes or gastrointestinal ulcer and as prevalent as asthma and chronic bronchitis [10]. continenza da urgenza.

I problemi che riguardano le stime sulla diffusione si estendono anche alla misurazione del fenomeno OAB. La maggior parte degli studi eseguiti hanno analizzato solo l'incontinenza, non tenendo in alcuna considerazione i sintomi di frequenza e di urgenza, anche se circa la metà di coloro i quali soffrono di OAB non presentano incontinenza da urgenza [3]. Non sono stati sviluppati questionari convalidati specifici sull'OAB con i quali analizzare la diffusione di OAB.

Per tali ragioni gli specialisti hanno raccomandato, in occasione della prima Consultazione Internazionale sulla Incontinenza, che gli strumenti di misurazione relativi ai sintomi relativi alla vescica nelle indagini a livello collettivo debbano essere standardizzati per un utilizzo su scala mondiale [2].

Nel complesso, approssimativamente 13 milioni di persone negli Stati Uniti d'America soffrono di incontinenza urinaria, con una diffusione maggiore tra le donne rispetto agli uomini [2]. Le stime suggeriscono che tale diffusione di incontinenza urinaria nelle donne possa raggiungere il 30\%. Un'indagine su 541 donne sane di età compresa tra i 42 e i 50 anni, condotta a Pittsburgh, ha evidenziato, ad esempio, che il 58\% delle intervistate ha subito alcune volte una perdita involontaria di urina, mentre il 31\% sperimenta episodi periodici di incontinenza, che registrano almeno un episodio al mese [4]. In generale, la diffusione dell'incontinenza aumenta con l'età (Tabella 1) e con il parto [5].

Un esame condotto su 21 studi ha rilevato che nelle donne che presentano incontinenza urinaria, il 49\% stimato soffre di incontinenza da stress, il 
Table 1 - Prevalence of urinary incontinence in US women according to age.

\begin{tabular}{lcc}
\hline Population & Prevalence & Reference \\
\hline Women aged $>60$ years & $38 \%$ & {$[6]$} \\
\hline Institutionalized elderly & $\geq 50 \%$ & {$[7,8]$} \\
\hline
\end{tabular}

An ongoing study of the prevalence of $\mathrm{OAB}$ in the US population, known as the National Overactive BLadder Evaluation (NOBLE) Program, will be the first to use a validated, OAB-specific questionnaire. The NOBLE Program will be the largest US study of bladder symptoms to date, with a planned recruitment of over 7000 individuals. It is anticipated that the data from this study will define the prevalence, impact and burden of $\mathrm{OAB}$ in the USA $[11,12]$.

\section{INCIDENCE OF BLADDER SYMPTOMS}

Few studies have sought to investigate the incidence of bladder symptoms. In one study, the cumulative incidence of chronic incontinence in previously continent women aged between 42 and 50 years was $8.0 \%$ over 3 years [4]. However, a study per-
$29 \%$ di incontinenza mista e il 22\% di incontinenza da urgenza [1].

Le stime sulla diffusione di OAB sono comprese tra i 17 milioni e i 71 milioni negli Stati Uniti d'America [9]. Ciò significa che, persino se si considera il valore più basso dell'intervallo, il fenomeno di $\mathrm{OAB}$ è più diffuso rispetto al diabete o all'ulcera gastrointestinale ed è diffuso al pari di asma e bronchite cronica [10].

Uno studio in corso relativo alla diffusione di OAB nella popolazione degli Stati Uniti, conosciuto come Programma NOBLE (National Overactive BLadder Evaluation), sarà il primo a utilizzare un questionario convalidato specifico sull'OAB. Il Programma NOBLE sarà il più vasto studio statunitense sui sintomi relativi alla vescica mai eseguito, con un reclutamento pianificato di oltre 7000 individui. E' stato anticipato che i dati derivati da questo studio definiranno la diffusione, l'impatto e la portata di OAB negli Stati Uniti d'America $[11,12]$.

\section{INCIDENZA DEI SINTOMI RELATIVI ALLA VESCICA}

Pochi studi hanno tentato di analizzare l'incidenza dei sintomi relativi alla vescica. In uno studio, l'incidenza cumulativa dell'incontinenza cronica in donne precedentemente continenti di età compresa tra i 42 e i 50 anni era 1'8.0\% in un periodo di 3 anni [4]. Uno 
formed in women aged between 65 and 104 years found that the incidences of stress and urge incontinence over a 3-year period were $28.6 \%$ and $28.5 \%$, respectively [13]. In a study in a managed-care settingin the USA, the incidence of incontinence and $\mathrm{OAB}$ was determined to be $1.4 \%$ and $1.0 \%$, respectively. The researchers noted the low incidence was probably due more to underreporting than to the lower age of the patients studied [14].

\section{IMPACT OF BLADDER SYMPTOMS ON QUALITY OF LIFE}

The impact of bladder symptoms on health-related quality of life (HRQoL) can be dramatic, as the symptoms influence many aspects of daily living, including psychological well-being, social and physical functioning, relationships and activities (see Figure 1). Urinary incontinence has a significant impact on social and psychological function, compared with age-matched controls [15], and also affects the lives of carers of the elderly or disabled [10].

It has been reported that urge incontinence has a greater impact on HRQoL than stress incontinence. This may be due to the unpredictability of the condition as well as the greater volume of fluid that is lost in urge incontinence, as well as lack of sleep due to nocturnal enuresis and nocturia. A study of employed women with urge incontinence recorded their concerns about job seeking and performance at work as a result of their studio eseguito tra donne di età compresa tra 65 e 104 anni ha tuttavia rilevato che le incidenze di incontinenza da stress e da urgenza in un periodo di 3 anni erano del $28.6 \%$ e del $28.5 \%$ rispettivamente [13]. In uno studio condotto in ambito ospedaliero negli Stati Uniti d'America, l'incidenza dell'incontinenza e di OAB è stata attestata a $1.4 \%$ e $1.0 \%$ rispettivamente. I ricercatori hanno individuato come causa della bassa incidenza non tanto la più giovane età dei pazienti studiati quanto una sottostima nelle segnalazioni [14].

\section{IMPATTO DEI SINTOMI RELATIVI ALLA VESCICA SULLA QUALITÃ DELLA VITA}

L'impatto dei sintomi relativi alla vescica sulla qualità della vita in relazione alla salute (HRQoL) può essere drammatico, poiché i sintomi influiscono su molti aspetti della vita quotidiana, inclusi il benessere psicologico, il funzionamento fisico e sociale, le relazioni e le attività (vedi Figura 1). L'incontinenza urinaria ha un impatto significativo sulla funzione psicologica e sociale, messa in relazione ai controlli corrispondenti all'età [15] e influisce inoltre sulle vite di coloro che si prendono cura degli anziani o dei disabili [10].

E' stato indicato che l'incontinenza da urgenza possiede un impatto maggiore sulla HRQOL rispetto all'incontinenza da stress. Ciò può essere determinato sia dalla imprevedibilità della condizione sia dal maggiore volume di fluido perso nel caso dell'incontinenza da urgenza, sia infine dalla mancanza di sonno dovuta alla enuresi notturna e alla nicturia. Uno studio su donne 
Figure 1 - Mean bealth-related quality of life scores and coefficients between quality of life and the number of micturitions and leakages [16].

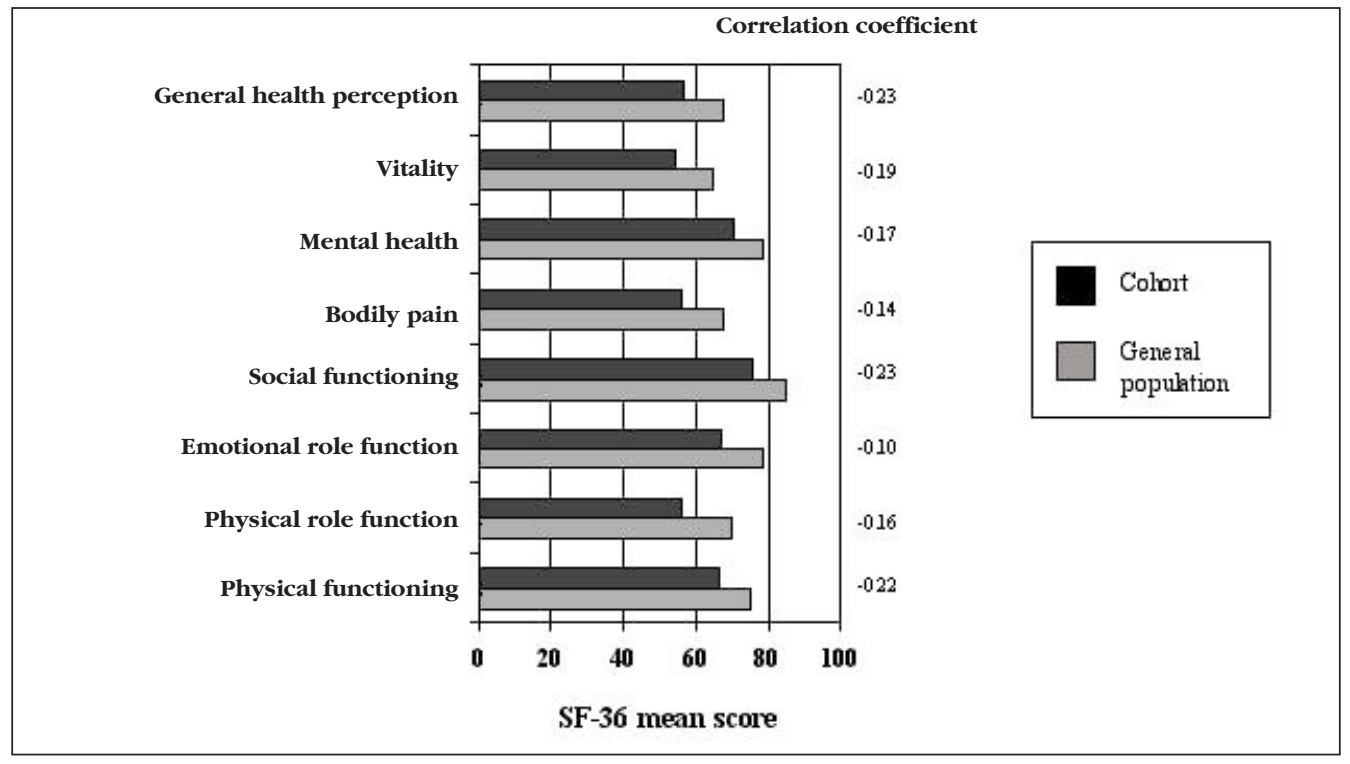

condition [17]. These women also reported that they felt unattractive, had low self-esteem and that urinary incontinence had an adverse effect on dating and sexual activities. Lenderking and colleagues [18] also found that fear of incontinence impaired sexual activity, as some women experience leakage during intercourse. Furthermore, it has been documented that the impact of OAB on HRQOL is greater than that seen with diabetes or hypertension [10, 19] (Figure 2).

There are few data on the impact of OAB without incontinence; although it has been suggested that patients with symptoms of frequency and urgency experience a decrease in HRQOL similar to patients with urge incontinence [20] [16]. The NOBLE Program has found that the symptoms of frequency and urgency impart a impiegate che soffrivano di incontinenza da urgenza ha registrato le loro preoccupazioni in relazione alla ricerca dal lavoro e alle prestazioni in ambito lavorativo come risultato della loro condizione [17]. Queste donne sostenevano inoltre di non sentirsi attraenti, di avere una bassa autostima e che l'incontinenza urinaria aveva un effetto inibitorio verso le attività sessuali o verso semplici appuntamenti. Lenderking e collaboratori [18] hanno inoltre dimostrato che la paura di fenomeni incontinenti danneggiava l'attività sessuale, visto che alcune donne soffrono di perdite durante il rapporto. Inoltre, è stato documentato che l'impatto di OAB sulla HRQoL è maggiore rispetto a quanto esaminato nel caso di diabete o ipertensione [10, 19] (Figura 2).

Esistono pochi dati sull'impatto di 
Figure 2 - OAB has a greater impact on HRQOL than diabetes or bypertension [19].

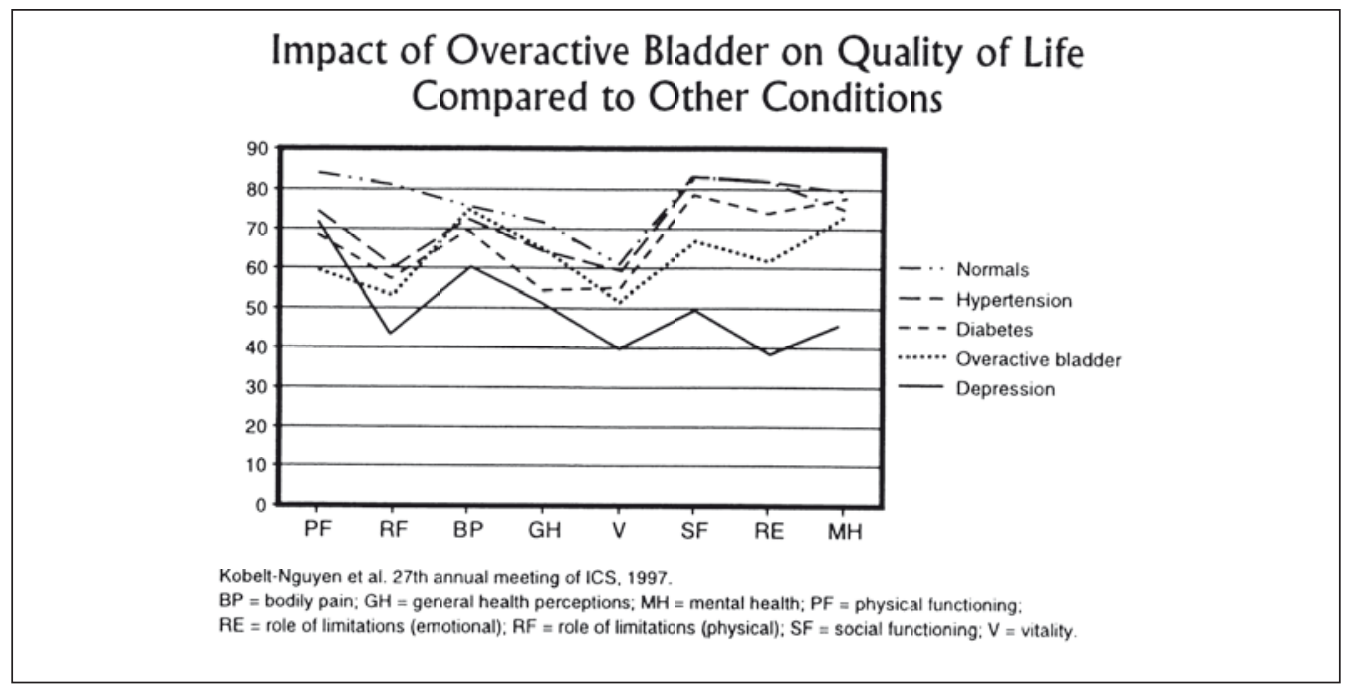

clinically significant reduction in quality of life, compared with the normal population [21]. As the prevalence of continent $\mathrm{OAB}$ patients is estimated to be very high, the economic impact is likely to be greater than that attributed to urge incontinence [10].
OAB non associato all'incontinenza; sebbene è stato suggerito che i pazienti con sintomi di frequenza e urgenza subiscano una diminuzione della HRQoL simile a quella dei pazienti con incontinenza da urgenza [20] [16]. Il Programma NOBLE ha rilevato che i sintomi di frequenza e di urgenza determinano una riduzione clinicamente significativa nella qualità della vita, a paragone con la popolazione normale [21]. Poiché la stima della diffusione dei pazienti di OAB continenti è molto alta, è probabile che l'impatto economico sia maggiore rispetto a quello attribuito all'incontinenza da urgenza [10].

\section{SUPPORTO PER LE DONNE CON INCONTINENZA URINARIA}

Ricerca sanitaria fra coloro che soffrono di sintomi relativi alla vescica

Nonostante la grande diffusione e l'impatto significativo sulla HRQoL dei 
Figure 3 - Proportion of middle-aged women with bladder symptoms not seeking treatment [4].

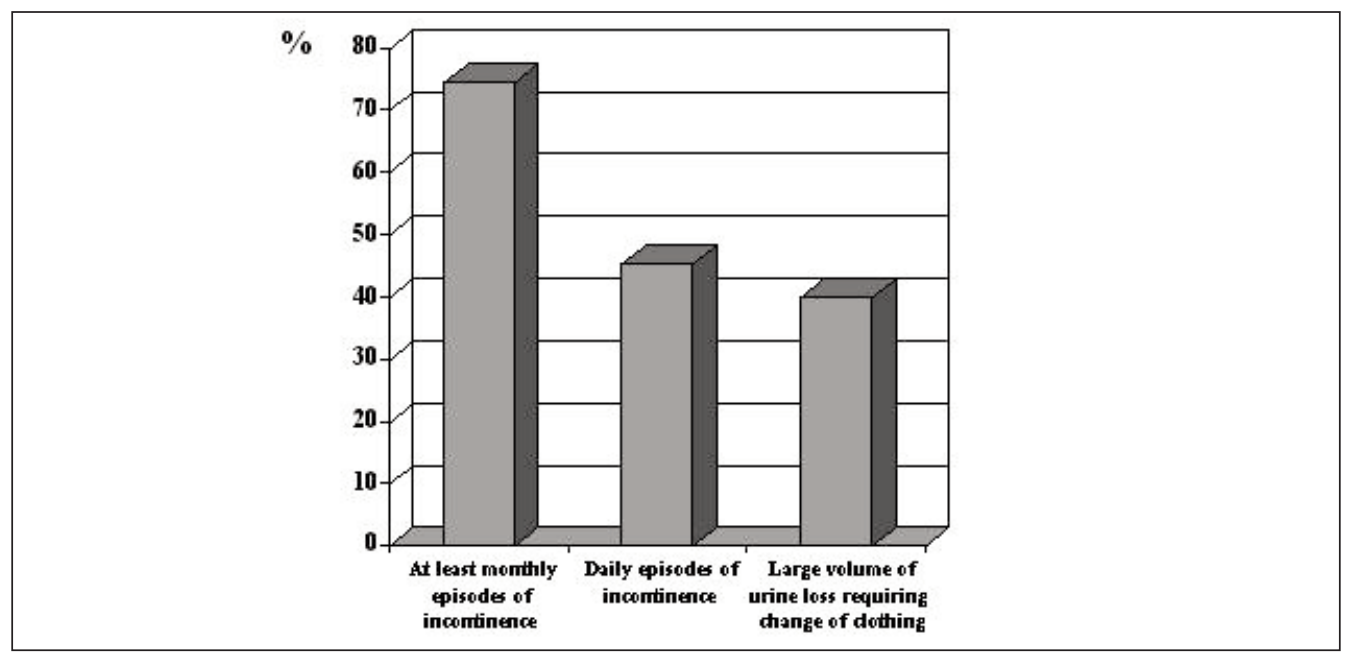

der symptoms, only a small proportion of women with urinary incontinence or $\mathrm{OAB}$ seek treatment for their condition, and they tend to seek help only when symptoms are severe (see Figure 3) [Burgio, 1991 \#25; [20].

Furthermore, women are less likely than men to have consulted a physician about their symptoms of urinary incontinence [22]. For example, although the prevalence of urinary incontinence in women over 50 years of age is approximately double that in men ( $48.7 \%$ versus $24.3 \%$ ), only $13 \%$ of the women had consulted a physician about their symptoms in the previous year compared with 29\% of the men.

Patients with bladder symptoms are often embarrassed about discussing their symptoms and believe that the symptoms are a natural consequence of childbirth or aging. They sintomi relativi alla vescica, soltanto una piccola porzione di donne che soffre di incontinenza urinaria o di $\mathrm{OAB}$ richiede un trattamento adeguato alla sua condizione. Tendenzialmente le donne chiedono aiuto quando i sintomi diventano gravi (vedi Figura 3) [Burgio, 1991 \#25; [20].

E' meno probabile, inoltre, che sia una donna piuttosto che un uomo a consultare il medico riguardo ai sintomi di IU [22]. Sebbene, ad esempio, la diffusione dell'IU tra le donne al di sopra dei 50 anni di età risulta approssimativamente doppia rispetto a quella degli uomini ( $47.7 \%$ versus $24.3 \%$ ), soltanto il 13\% delle donne ha consultato un medico riguardo ai sintomi negli anni precedenti rispetto al 29\% degli uomini.

Le pazienti che soffrono dei sintomi relativi alla vescica sono spesso imbarazzate dal discutere i loro sintomi e credono che questi siano una conse- 
are not aware that effective treatment is available. This is compounded by the fact that bladder function is not included in routine consultations with family practitioners, even for highrisk patients. [23]

\section{Coping strategies}

Rather than seeking help for their bladder symptoms, most sufferers develop coping strategies.

The MESA survey found that just over half of women with urinary incontinence used absorbent materials to manage their urine leakage [24]. Incontinence pads are available at pharmacies, but the costs are generally not reimbursed by the medical insurance companies. Consequently, the full cost of these items is borne by the patient. As much as US\$4.5 billion is spent each year on incontinence pads. Although the use of absorbent materials enables the patient to deal with the immediate problem of leakage, it does not address the cause of urinary incontinence. Furthermore, pad use also leads to skin irritation and infection [25, 26].

More complex coping strategies may be implemented to cope with the symptoms of frequency and urgency, including dietary changes and fluid restriction at night, bathroomseeking immediately upon arrival at an unfamiliar place and planning restroom visits [24]. Wyman and colleagues [27] found that activities involving unfamiliar places where the availability of toilets was not known, such as shopping, entertainment, guenza naturale del parto o dell'invecchiamento. Esse non sono consapevoli del fatto che è disponibile un trattamento efficace. Tale problema è accentuato dal fatto che la funzionalità della vescica non è considerata nei consulti di routine che si hanno con il medico di famiglia, persino per i pazienti ad alto rischio. [23]

\section{Metodi di contenimento personali}

Piuttosto che chiedere supporto per i sintomi relativi alla vescica, la maggior parte di coloro che ne soffrono sviluppano dei metodi di contenimento personali.

L'indagine MESA ha rivelato che più della metà delle donne che soffrivano di incontinenza urinaria utilizzavano materiali assorbenti per gestire le loro perdite di urina [24]. I tamponi per l'incontinenza sono disponibili nelle farmacie, ma il loro costo non è, in genere, rimborsato dalle compagnie assicurative mediche. Di conseguenza, l'intero costo di questi articoli grava sul paziente. Negli Stati Uniti ogni anno si spendono $\$ 4.5$ miliardi in tamponi per l'incontinenza. Anche se l'utilizzo di materiali assorbenti consente al paziente di gestire nell'immediatezza il problema della perdita, esso non risolve la causa dell'incontinenza urinaria. L'utilizzo del tampone, inoltre, determina anche infezioni e irritazioni della pelle [25, 26].

E' possibile attuare metodi di contenimento personali più complessi per far fronte ai sintomi di frequenza e urgenza, incluse modifiche alla dieta e limitazioni di fluidi durante la notte, la ricerca immediata del bagno all'arrivo in luoghi sconosciuti e la pianificazione della frequenza con cui si va al ba- 
long-distance travel and vacations, were seriously affected by urinary incontinence and OAB. While the adoption of coping strategies may lessen the incidence of 'accidents', they add to the burden of the disease [10]. Furthermore, although the coping strategies may begin as minor changes to daily activities, they may progress to such a level that sufferers are prevented from carrying out their usual activities, for example avoiding travelling or visiting relatives.

\section{Role of primary care}

The family practitioner is often the first person who women with urinary incontinence consult, but individual healthcare plans may permit them to consult directly with a urologist or a gynecologist without referral from a primary care physician. For elderly patients, a geriatrician is often the first person to diagnose and treat their condition.

However, before any consultation takes place, both patient and physician need to be aware of the need to evaluate and treat symptoms. At present, there are no formal tools available to assist and encourage communication between doctors and patients about bladder symptoms. Furthermore, $\mathrm{OAB}$ was not classified as a disease under the International Classification of Diseases (ICD version 9), gno [24]. Wyman e collaboratori [27] hanno evidenziato che le attività che coinvolgevano luoghi sconosciuti nei quali la disponibilità delle toilette non era nota, come ad esempio negozi e luoghi di divertimento, vacanze e viaggi a lunga distanza, erano seriamente pregiudicate dall'incontinenza urinaria e dal fenomeno di OAB. Anche se l'adozione di metodi di contenimento personali può ridurre l'incidenza di "infortuni", tutte queste accortezze si aggiungono al pesante carico della malattia [10]. In aggiunta, sebbene i metodi di contenimento personali possono incidere inizialmente come modifiche minori alle attività giornaliere, queste possono progredire a un livello tale da impedire ai malati di portare avanti le loro usuali attività, ad esempio evitando viaggi e visite ai parenti.

\section{Ruolo delle cure di base}

Il medico di famiglia è spesso la prima persona che le donne con incontinenza urinaria consultano, ma i piani sanitari individuali possono consentire alle pazienti di consultare direttamente un urologo o un ginecologo senza alcuna prescrizione da parte di un medico di base. Per i pazienti anziani, un geriatra è spesso la prima persona a diagnosticare e curare la loro condizione.

Prima che avvenga una consultazione di qualche tipo, comunque, sia il paziente che il dottore devono essere consapevoli della necessità di valutare e curare in modo appropriato i sintomi. Al presente, non esistono strumenti convenzionali disponibili per assistere e incoraggiare la comunicazione tra dottori e pazienti sui sintomi relativi alla vescica. In aggiunta, il fenomeno di 
which has inhibited reimbursement for treatment. In addition, although guidelines for the diagnosis and treatment of urinary incontinence have been developed and recently revised by the Agency for Health Care Policy and Research (AHCPR) [28], they are not widely used by primary care physicians in the USA, and do not address the OAB symptoms of frequency and urgency.

\section{PREVENTION PROGRAMS}

\section{Initiatives to improve patient-physician communication}

It is generally accepted that the bladder symptoms associated with OAB should be diagnosed and managed in primary care. However, this is dependent upon the development of a clinically validated screening tool.

Communication about bladder symptoms between patient and physician is an important prerequisite for the recognition of those requiring intervention and the allocation of treatment, many of which are effective at lessening the burden of symptoms and increasing HRQOL. In fact, the AHCPR guidelines recommend that patients and their families should be taught that incontinence is not inevitable or shameful, but is a condition that is treatable or, at least, manageable [28].

A number of recent initiatives by the American Urological Association (AUA), the American Foundation for Urologic Disease (AFUD) and the American Medical Women's Associa-
OAB non è stato classificato come una malattia all'interno dell'International Classification of Diseases (ICD versione 9), il che ha impedito il rimborso per il trattamento. Inoltre, sebbene gli orientamenti relativi alla diagnosi e al trattamento dell'incontinenza urinaria sono stati sviluppati e recentemente riveduti dall'AHCPR (Agency for Health Care Policy and Research) [28], essi non sono ancora diffusamente utilizzati dai medici di base negli USA e non tengono in considerazione i sintomi di frequenza e di urgenza della OAB.

\section{PROGRAMMI DI PREVENZIONE}

\section{Iniziative volte ad migliorare la co- municazione paziente-medico}

Viene generalmente accettato il fatto che i sintomi relativi alla vescica associati all'OAB debbano essere diagnosticati e gestiti tramite cure di base. Ciò è, tuttavia, dipendente dallo sviluppo di uno strumento di screening clinicamente convalidato.

La comunicazione tra paziente e medico relativa ai sintomi vescicali risulta essere un importante prerequisito per il riconoscimento degli interventi necessari e per l'assegnazione del trattamento, molti dei quali sono efficaci nella riduzione del carico dei sintomi e nel miglioramento della HRQoL. Gli orientamenti della AHCPR, infatti, evidenziano la necessità di insegnare ai pazienti e alle loro famiglie che l'incontinenza non è inevitabile o disonorevole, ma che si tratta di una condizione che è possibile curare o, quanto meno, gestire [28].

Una serie di recenti iniziative condotte dall'American Urological Association (AUA), dall'American Foundation 
Table 2 - Website details of key associations and organizations.

\begin{tabular}{ll}
\hline Organization & Website address \\
\hline AUA & $\begin{array}{l}\text { www.drylife.org } \\
\text { www.auanet.org }\end{array}$ \\
\hline AFUD & www.afud.org \\
\hline AMWA & www.amwa-doc.org \\
\hline ICS & www.continet.org \\
\hline AUGS & www.augs.org \\
\hline National Association for Continence & www.nafc.org \\
\hline Simon Foundation & www.simonfoundation.org \\
\hline Italian UroGynecological Association & www.aiug.it \\
\hline
\end{tabular}

tion (AMWA) have all sought to raise awareness of the problems of urinary incontinence and $\mathrm{OAB}$ and to encourage women to discuss their symptoms with their physician. Initiatives such as National Bladder Health Week, which is organized in November each year by the Bladder Health Council of the AFUD, are designed to increase public awareness of urinary incontinence and OAB. The AFUD has also established free telephone helplines for patients and their families to obtain information about bladder conditions. A wide range of public support groups is available for the woman with urinary incontinence. In addition to those mentioned above, these include international organizations such as Continence Worldwide and the ICS, and national organizations, such as the American Urogynecological Society (AUGS), the National Association for Continence, the Simon Foundation for Continence and the Alliance for Aging Research.

Education programs and support groups such as these, directed at patients themselves and the public as a for Urological Disease (AFUD) e dall'American Medical Women's Association (AMWA) hanno cercato di accrescere la consapevolezza verso i problemi legati all'incontinenza urinaria e al fenomeno $\mathrm{OAB}$ e di incoraggiare le donne a discutere dei loro sintomi con il loro medico. Iniziative come la $\mathrm{Na}$ tional Bladder Health Week (Settimana per la Salute della Vescica a livello $\mathrm{Na}$ zionale), organizzata in novembre ogni anno dal Bladder Health Council dell'AFUD, aumentano la consapevolezza del pubblico verso l'incontinenza urinaria e l'OAB. L'AFUD ha inoltre stabilito delle linee telefoniche di soccorso gratuite rivolte ai pazienti e ai loro famigliari affinché ottengano informazioni che toccano il campo che riguardano la vescica, il suo stato, le condizioni, ecc. Una vasta gamma di gruppi di supporto a livello pubblico è disponibile per le donne che soffrono di incontinenza urinaria. In aggiunta alle associazioni menzionate in precedenza, tali gruppi contano anche la presenza di organizzazioni internazionali come, ad esempio, Continence Worldwide e ICS, e di organizzazioni 
whole, play an important role in eliminating the taboo associated with bladder symptoms.

The NOBLE Program will also serve to increase awareness of bladder symptoms and will provide a validated questionnaire that can be used in primary care to identify bladder symptoms requiring intervention. The questionnaire will guide diagnosis and management and, importantly, it will prompt discussion between patient and physician. During the Program, patients with $\mathrm{OAB}$ will be followed to assess the impact of treatment on their symptoms and lifestyle, and to study the natural history of the condition. It is also hoped that the NOBLE Program may determine whether early treatment of bladder symptoms such as frequency and urgency will help prevent potential progression to urge incontinence.

The AHCPR guidelines also recommend that professional education about the evaluation and treatment of urinary incontinence should be included in both undergraduate and graduate training programs for all healthcare professionals, as well as in continuing education programs. To support this need, the World Health Organization (WHO) has included $\mathrm{OAB}$ as a 'disease' in the latest revision of the ICD - ICDCM-9. nazionali come, ad esempio, American Urogynecological Society (AUGS), National Association for Continence, Simon Foundation for Continence e Alliance for Aging Research.

I programmi di istruzione e i gruppi di supporto, diretti a pazienti singoli e al pubblico, giocano un ruolo importante nel tentativo di eliminare ogni taboo associato ai sintomi relativi alla vescica. Il Programma NOBLE sarà utile inoltre per accrescere la consapevolezza verso i sintomi relativi alla vescica e fornirà un questionario convalidato che potrà essere utile nelle cure primarie per identificare i sintomi relativi alla vescica che richiedono un intervento. Il questionario guiderà la diagnosi e la gestione e, cosa più importante, solleciterà una discussione tra paziente e medico. Durante il Programma, i pazienti affetti da OAB verranno seguiti per accertare quale sia l'impatto del trattamento sui sintomi e lo stile di vita, e per studiare l'evolversi naturale della condizione. Si spera che il Programma NOBLE consenta di determinare se il trattamento precoce dei sintomi vescicali, come ad esempio la frequenza e l'urgenza, possa aiutare a evitare la potenziale progressione verso l'incontinenza da urgenza. Gli orientamenti dell'AHCPR raccomandano che venga inclusa l'istruzione professionale relativa alla valutazione e al trattamento dell'incontinenza urinaria sia nei programmi di addestramento universitari e post-universitari per tutti i professionisti della salute che nella continuazione dei programmi d'insegnamento. La World Health Organization (WHO) ha incluso l'OAB come "malattia" nell'ultima revisione dell'ICD - ICDCM-9. 


\section{MANAGEMENT OF URINARY INCONTINENCE}

A number of different approaches may be employed to manage urinary incontinence, including behavioral therapies, pharmacotherapy and surgery. The choice of treatment for an individual patient is determined by the nature and severity of the symptoms.

\section{Behavioral therapies}

Regular daily exercises that strengthen the muscles of the pelvic floor (Kegel exercises) and help to reduce leakage are the first-line therapy for women with mild to moderate stress incontinence [29]. Kegel exercises have been reported to improve mild to moderate stress incontinence in $54 \%$ of cases, with remission in $16 \%$ of cases $[30,31]$. They have also been reported to improve the symptoms of OAB [30, 31]. Biofeedback, which helps women to gain awareness and control of the pelvic muscles, and electrical stimulation of the pelvic floor musculature can be employed to increase the effectiveness of Kegel exercises. Vaginal cone exercises are another method of strengthening the pelvic floor muscles [29], and may be useful in the treatment of women with stress incontinence. Bladder training techniques, in which the patient is taught to resist the urge to pass urine and gradually increase the intervals between voiding, may be used successfully in the treatment of women with urge incontinence and $\mathrm{OAB}$ [29] [32]. The aim of bladder training is to increase the capacity of the bladder and so reduce the number of episodes of incontinence [32].

\section{GESTIONE DELL'INCONTINENZA URINARIA}

E' possibile impiegare un numero di approcci differenti nella gestione dell'incontinenza urinaria, incluse le terapie comportamentali, la terapia farmacologica e la chirurgia. La scelta del trattamento per un singolo paziente viene determinata dalla natura e dalla gravità dei sintomi.

\section{Terapie comportamentali}

I regolari esercizi giornalieri che rafforzano i muscoli del pavimento pelvico (esercizi di Kegel) e aiutano a ridurre la perdita rappresentano la principale terapia per le donne che soffrono di una forma di incontinenza da stress che varia da lieve a moderata [29]. E' stato dimostrato che gli esercizi di Kegel determinano un miglioramento in una forma di incontinenza da stress che varia da lieve a moderata nel 54\% dei casi, con una regressione nel 16\% dei casi $[30,31]$. E' stato inoltre dimostrato che questi esercizi determinano un miglioramento dell'OAB [30,31]. Il Biofeedback, che aiuta le donne ad acquisire consapevolezza e controllo dei muscoli pelvici, e la stimolazione elettrica della muscolatura del pavimento pelvico possono essere impiegati per aumentare l'efficacia degli esercizi di Kegel. I coni vaginali rappresentano un altro metodo di rafforzamento dei muscoli del pavimento pelvico [29] e possono risultare utili nel trattamento dell'incontinenza da stress. Le tecniche di training della vescica, nelle quali al paziente viene insegnato a resistere allo stimolo di urinare e ad aumentare progressivamente l'intervallo tra gli svuotamenti, possono essere utilizzate con esito po- 
However, compliance with bladder exercises and training is often poor [33].

\section{Pharmacotherapy}

Pharmacotherapy may be used in addition to or instead of behavioral techniques for the management of both stress and urge incontinence. It is possible that the a-adrenergic agonists, such as phenylpropanolamine, which increase tone in the proximal urethra, may help to reduce urine loss in women with stress incontinence $[34,35]$ but such therapy is rarely used because of concern over adverse events. Estrogen replacement therapy in combination with an aadrenergic agonist have been shown to be effective in post-menopausal women with stress incontinence [34, 35] but again, because of concern over adverse events, these therapies are rarely used.

A number of different agents may be used to treat urge incontinence and $\mathrm{OAB}$, including antimuscarinic drugs, such as tolterodine, oxybutynin, propantheline and hyoscyamine, the smooth muscle relaxant flavoxate and the tricyclic antidepressant imipramine. There is also evidence that estrogen replacement therapy can be beneficial in the management of $\mathrm{OAB}$ and mixed incontinence in some post-menopausal women [36] by alleviating symptoms of frequency, urgency, urge inconti- sitivo nel trattamento di donne con incontinenza da urgenza e OAB [29] [32]. L'obiettivo del training della vescica è quello di aumentare la capacità della vescica e di ridurre, di conseguenza, il numero di episodi di incontinenza [32]. L'adesione agli esercizi e al training della vescica, comunque, rimane spesso scarsa [33].

\section{Terapia farmacologica}

La terapia farmacologica può essere utilizzata in aggiunta $\mathrm{o}$ in sostituzione delle tecniche comportamentali per la gestione sia dell'incontinenza da stress che da urgenza. E' possibile che gli agonisti alfa adrenergici, come ad esempio la fenilpropanolamina, che migliorano il tono nell'uretra prossimale, possano essere di aiuto nel ridurre la perdita di urina nelle donne con incontinenza da stress [34, 35], ma tale terapia viene utilizzata raramente a causa delle preoccupazioni destate dagli effetti collaterali. La terapia combinata che utilizza la supplementazione di estrogeni e un agonista alfa adrenergico ha evidenziato un'efficacia nelle donne in menopausa che soffrono di incontinenza da stress [34, 35], ma ancora, a causa delle preoccupazioni sugli effetti collaterali, queste terapie vengono utilizzate di rado.

E' possibile utilizzare una serie di agenti diversi per il trattamento dell'incontinenza da urgenza e dell'OAB, inclusi i farmaci antimuscarinici, come ad esempio tolterodina, ossibutinina, propantelina e iosciamina, il flavossato rilassante della muscolatura liscia e l'imipramina antidepressivo triciclico. E' anche dimostrato che la terapia estrogenica dia benefici nella gestione del fenomeno $\mathrm{OAB}$ e nell'incontinenza mi- 
nence and nocturia [36]. Studies have shown that oxybutynin (Ditropan ${ }^{\circledR}$ ), initially developed for its effects on the gastrointestinal system, lowers intravesical pressure, increases bladder capacity and reduces the frequency of bladder contractions [37]. However, its use is associated with profound antimuscarinic side effects, especially dry mouth and including, but not limited to, constipation and blurred vision. Discontinuation rates with oxybutynin may be as high as 60\% [38]. Indeed, one study of treatment outcomes in women with OAB found that among those who received anticholinergic agents, of which oxybutynin was the most frequently prescribed (83.5\% of patients), only $11.4 \%$ continued to take their medication for more than 6 months [38]. Furthermore, oxybutynin has been shown to cause cognitive impairment in elderly volunteers [39], which is of concern given the high prevalence of urinary incontinence among the elderly population. Oxybutynin is listed as potentially inappropriate for use in elderly patients [40]. An extended-release formulation of oxybutynin (Ditropan XL") was developed in the hope that it would result in fewer incidences of dry mouth. However, a recent study [41] was unable to demonstrate any difference in efficacy or the mean dry mouth rate between the immediate-release and extended-release formulations of oxybutynin.

Tolterodine was developed specifically for use in $\mathrm{OAB}$ and may show benefits over other available agents. Tolterodine shows selectivity for muscarinic receptors in the bladder over sta in alcune donne entrate in menopausa [36] alleviando i sintomi di frequenza, urgenza, di incontinenza da urgenza e di nocturnia [36]. Gli studi hanno evidenziato che la ossibutinina (Ditropan ${ }^{\circledR}$ ), sviluppata inizialmente per i suoi effetti sul sistema gastrointestinale, diminuisce la pressione intravescicale, aumenta la capacità della vescica e riduce la frequenza delle contrazioni della vescica [37]. Il suo utilizzo, tuttavia, viene associato a forti effetti collaterali legati all'antimuscarinico, specialmente la secchezza delle fauci e inclusi, ma non limitati ad essi, la costipazione e la vista annebbiata. Il tasso di discontinuità nel caso della ossibutinina può raggiungere livelli del $60 \%$ [38]. Infatti, uno studio sui risultati del trattamento nelle donne con problemi di OAB ha evidenziato che tra coloro i quali hanno ricevuto gli agenti anticolinergici, tra i quali l'ossibutinina è la più frequentemente prescritta (83.5\% dei pazienti), soltanto 1'11.4\% ha continuato ad assumere la medicina per un periodo superiore a 6 mesi [38]. In aggiunta, è stato dimostrato che l'ossibutinina causa un peggioramento a livello cognitivo nei volontari anziani [39], cosa che risulta preoccupante se si considera l'alta diffusione dell'IU tra la popolazione anziana. L'ossibutinina viene elencata come potenzialmente inappropriata per l'utilizzo nei pazienti anziani [40]. Una preparazione a rilascio ritardato di ossibutinina (Ditropan XL $\left.{ }^{\circledR}\right)$ è stata sviluppata nella speranza che possa avere come conseguenza una minore incidenza di effetti collaterali. Uno studio recente [41], tuttavia, non è stato capace di dimostrare alcuna differenza in efficacia o un'incidenza minore del fenomeno della secchez- 
those in the salivary glands in both in vitro and in vivo studies [42]. Clinical studies have shown that tolterodine, $2 \mathrm{mg}$ twice daily, is as effective as oxybutynin, $5 \mathrm{mg}$ three times daily, in reducing the frequency of micturition and the number of incontinence episodes and in increasing the volume of urine voided per micturition [43, 44]. Typically, the mean daily micturition frequency was reduced by approximately 20\% from baseline by both tolterodine and oxybutynin, and mean daily incontinence episodes were reduced by $40-60 \%$ by both treatments. However, the tolerability profile of tolterodine, and hence the potential for treatment compliance, is superior to that of oxybutynin [43, 44]. The percentage of patients reporting dry mouth as an adverse effect was significantly higher among patients receiving oxybutynin (up to 86\%) compared with tolterodine-treated patients (almost 40\%), as was the percentage of patients reporting moderate or severe dry mouth (up to 60\% with oxybutynin compared with approximately $20 \%$ for tolterodine) [ 43 , $44]$. Consequently, the number of patients who withdrew from the studies because of this adverse effect was greater in the oxybutynin groups than in the tolterodine groups. The number of patient withdrawals from treatment with tolterodine has been shown to be similar to placebo $(6 \%$ in placebo groups versus $5 \%$ in tolterodine group) [45]. A recent report [46] showed that the newly developed extended-release formulation of tolterodine demonstrated a statistically significant improvement in incontinence episodes and reduction in za delle fauci tra le preparazioni a rilascio immediato e rilascio ritardato di ossibutinina.

La tolterodina è stata sviluppata precisamente per un utilizzo nel fenomeno di OAB e può determinare benefici superiori ad altri agenti disponibili. La tolterodina evidenzia una selettività riguardo ai recettori muscarinici presenti nella vescica maggiore rispetto a quelli presenti nelle ghiandole salivali sia negli studi in vitro che in vivo [42]. Gli studi clinici hanno indicato che la tolterodina, $2 \mathrm{mg}$ due volte al giorno, ha un grado di efficacia pari a quello della ossibutinina, $5 \mathrm{mg}$ tre volte al giorno, nella riduzione della frequenza minzionale e del numero di episodi di incontinenza e nell'aumento del volume di urina svuotato per minzione [43, 44]. La quantità media di minzione giornaliera è stata, in genere, ridotta di circa il 20\% sia grazie alla tolterodina che all'ossibutinina, e il numero medio di episodi di incontinenza è stato ridotto al 40-60\% da entrambi i trattamenti. Il profilo di tollerabilità della tolterodina, comunque, e conseguentemente il potenziale per l'adesione al trattamento, è superiore rispetto a quello dell'ossibutinina [43, 44]. La percentuale di pazienti che sperimentavano "bocca asciutta" come effetto collaterale risultava essere significativamente maggiore tra i pazienti curati con ossibutinina (fino a 86\%) rispetto ai pazienti trattati con tolterodina (quasi il 40\%), e lo stesso risultato lo si otteneva nella percentuale di pazienti che sperimentavano un grado di secchezza delle fauci variabile da moderato a grave (fino al 60\% con l'ossibutinina rispetto a circa il 20\% per la tolterodina) [43, 44]. Di conseguenza, il nu- 
dry mouth, compared with the immediate-release formulation of tolterodine.

Market assessment in 2000 showed that tolterodine is the most frequently prescribed product for $\mathrm{OAB}$ in the USA, exceeding both controlled-release and immediate-release formulations of oxybutynin. The assessment also showed that tolterodine is the most commonly prescribed molecule in the USA [47].

\section{Surgery}

\section{Stress incontinence}

Surgery is reserved for women with stress urinary incontinence who have failed to respond to behavioral therapy. Essentially, there are three approaches:

1. Injection therapy

2. Urethropexy

3. Sling procedures

\section{Injection therapy}

Genuine stress incontinence occurs mero di pazienti che si ritirava da questi studi a causa di questo effetto collaterale era maggiore nei gruppi curati con ossibutinina rispetto ai gruppi curati con tolterodina. E' stato evidenziato che il numero di pazienti che si ritira dal trattamento con tolterodina è simile a quello che si ritira dal trattamento con placebo (6\% nei gruppi trattati con placebo versus 5\% nel gruppo che utilizza la tolterodina) [45]. Una recente relazione [46] evidenzia che la preparazione a rilascio ritardato di tolterodina ha dimostrato un miglioramento statisticamente significativo negli episodi di incontinenza, se paragonato alla preparazione a rilascio immediato di tolterodina.

Le stime di mercato condotte nel 2000 hanno rilevato che la tolterodina risulta il prodotto prescritto più di frequente per l'OAB negli USA, superando sia la preparazione a rilascio immediato che quella a rilascio ritardato di ossibutinina. Tali stime dimostrano inoltre che la tolterodina è la molecola più comunemente prescritta negli USA [47].

\section{Chirurgia}

\section{Incontinenza da stress}

La chirurgia è riservata alle donne che soffrono di un'incontinenza urinaria da stress e che hanno tentato senza successo la terapia comportamentale. Essenzialmente esistono tre tipi di approcci:

1. Terapia per infiltrazione

2. Uretropessi

3. Procedure di sling

\section{Terapia per infiltrazione}

L'incontinenza da stress autentica si 
because there is failure of the internal (bladder neck) and external urethral sphincter. The goal of injection therapy is to apply a bulking agent to the bladder neck to 'reconstruct' the internal sphincter. Many bulking agents have been tried and several are under development. Currently, the most commonly used is GAX (gluteraldehyde cross-linked) bovine collagen. As this is fairly expensive some surgeons have instead tried using endogenous fat but difficulty with harvesting and administering the fat limit its use. GAX collagen is indicated for the treatment of intrinsic sphincteric deficiency; for reimbursement, Medicare requires that the diagnosis be proven by documentation of a pre-procedure urethral leak point pressure of greater than 100 $\mathrm{cmH}_{2} \mathrm{O}$. Furthermore, practitioners are only allowed to use the GAX collagen technique after certification through the AUA.

\section{Urethropexy}

The main aim of suspension procedures to treat stress incontinence is to relocate the bladder neck within the intra-abdominal pressure zone and so optimize urethral sphincter function [48]. The techniques used include primarily anterior repair and the Burch colposuspension and in some cases the Marshall-MarchettiKrantz procedure. Anterior repairs for stress incontinence tend to be carried out by generalists but are not favored by specialists given the high failure rate (about 50\%) [49]. The Burch col- verifica a causa di un malfunzionamento dello sfintere uretrale (collo vescicale) interno ed esterno. L'obiettivo della terapia per iniezione è quello di applicare un agente che aggiunga volume al collo vescicale per "ricostruire" lo sfintere interno. Sono stati provati molti agenti che aggiungono volume e numerosi agenti sono in fase di sviluppo. Attualmente quello più frequentemente utilizzato è il collagene di origine bovina GAX (gluteraldeide a legami incrociati). Poiché si tratta di un prodotto estremamente costoso, alcuni chirurghi hanno tentato di utilizzare al suo posto il grasso endogeno ma la difficoltà riscontrata nel conservare e somministrare tale grasso limita il suo utilizzo. Il GAX è indicato per il trattamento della insufficienza intrinseca dello sfintere; per il rimborso, Medicare richiede che la diagnosi venga dimostrata da una documentazione che attesti una pressione uretrale, precedente alla chirurgia, maggiore di $100 \mathrm{cmH}_{2} \mathrm{O}$. Inoltre l'utilizzo del GAX viene consentito ai medici soltanto dopo una certificazione acquisita tramite la AUA.

\section{Uretropessi}

Lo scopo principale delle procedure di sospensione nel trattare l'incontinenza da stress è quello di riposizionare il collo vescicale all'interno della zona di pressione intra-addominale e, di conseguenza, ottimizzare la funzionalità dello sfintere uretrale [48]. Le tecniche utilizzate comprendono principalmente la riparazione anteriore, la colposospensione di Burch e, in alcuni casi, la procedura Marshall-MarchettiKrantz. Le riparazioni anteriori per l'incontinenza da stress vengono tendenzialmente compiute da urologi o gine- 
posuspension and the Marshall-Marchetti-Krantz procedure have both been reported to cure urinary incontinence in approximately $90 \%$ of women undergoing surgery for the first time, although the cure rate drops to approximately $80 \%$ if surgery has to be repeated [50]. Over the last decade, laparoscopic urethropexy has gained popularity because of the relatively reduced level of post-operative pain and length of hospital stay. While uncontrolled trials suggest that the cure rates for these minimally invasive procedures are similar to those for the open procedures, two randomized controlled studies have indicated that the open procedures are superior [51] [52].

\section{Sling procedures}

The pubo-vaginal sling procedure is popular among urologists as a primary procedure for stress incontinence as it has an equivalent success rate to the Burch colposuspension. However, it is associated with a higher risk of postoperative $\mathrm{OAB}$ and voiding difficulty [48]. Urogynaecologists tend to utilise the Burch colposuspension as the primary procedure as often this may be combined with a paravaginal repair for correction of a concomitant cystocele.

The last couple of years has seen the introduction of the tension-free vaginal tape (TVT) procedure which is inserted, often under local anes- cologi generali ma non sono viste con favore dai medici specializzati a causa dell'alto tasso di fallimento (circa il 50\%) [49]. E' stato dimostrato che sia la colposospensione di Burch che la procedura Marshall-Marchetti-Krantz curano l'incontinenza urinaria in circa il 90\% delle donne che si sono sottoposte a trattamento chirurgico per la prima volta, anche se il tasso di cura scende fino a circa $1{ }^{\prime} 80 \%$ se il trattamento chirurgico deve essere ripetuto [50]. Nell'ultima decade, l'uretropessilaparoscopica ha ottenuto una estesa popolarità grazie al livello relativamente ridotto dei dolori post operatori e della lunghezza di degenza ospedaliera. Mentre esperimenti non verificati suggeriscono che i tassi di cura associati a queste procedure siano simili a quelli registrati per le procedure chirurgiche più invasive, due studi randomizzati hanno indicato che tali tassi aumentano nei trattamenti chirurgici più invasivi [51] [52].

\section{Procedure di sling}

La procedura di sling pubo-vaginale è diffusa tra gli urologi come una procedura primaria per l'incontinenza da stress poiché ha un tasso di riuscita equivalente alla colposospensione di Burch. Essa viene associata, tuttavia, a un rischio maggiore di $\mathrm{OAB}$ post operatorio e di difficoltà di svuotamento [48]. Gli uro-ginecologi tendono a utilizzare la colposospensione di Burch come procedura principale ogni volta che essa può essere combinata a una riparazione paravaginale per la correzione di un cistocele concomitante.

Negli ultimi anni si è assistito all'introduzione della procedura TVT (tension-free vaginal tape-nastro vaginale 
thetic, through the anterior wall of the vagina. A recent randomized controlled trial comparing TVT with Burch colposuspension demonstrated lower short-term morbidity and equivalent efficacy with TVT [53].

\section{Overactive bladder}

No surgical treatments have been advocated for continent $\mathrm{OAB}$ but one procedure which has been shown to be of some benefit for the treatment of urge incontinence is sacral nerve stimulation with an implantable stimulator [54]. Further trials with this device need to be performed before it can be advocated for widespread usage. The surgical treatment of last resort for urge incontinence is augmentation cystoplasty, in which the capacity of the bladder is increased so that contractions of the bladder during the filling phase do not result in leakage of urine. Cystoplasty may involve either the incorporation of a portion of bowel into the dome of the bladder (a procedure known as enterocystoplasty) or excision of a large portion of detrusor muscle with preservation of the underlying mucosa to allow development of a diverticulum (a procedure known as autoaugmentation) [55]. Although enterocystoplasty is effective, complications may include inadequate voiding, retention of mucus and electrolyte imbalance. Auto-augmentation avoids the post-operative morbidity that may develop following enterocystoplasty, but it is not considered to be as effective [9]. senza tensione) che viene inserito, spesso in anestesia locale, attraverso la parete della vagina. Un recente esperimento controllato in maniera random ha confrontato la procedura TVT con la colposospensione di Burch dimostrando una minore morbidità a breve termine e un'efficacia equivalente con TVT [53].

\section{Iperattività vescicale (OAB)}

Nessun trattamento chirurgico è stato patrocinato per il fenomeno di $\mathrm{OAB}$ continente, ma una procedura che è stata indicata essere di qualche beneficio per il trattamento dell'incontinenza da urgenza è la stimolazione del nervo sacrale con uno stimolatore impiantabile [54]. Ulteriori esperimenti con questo dispositivo devono ancora essere eseguiti prima che ne venga patrocinato un utilizzo più diffuso. Come ultima risorsa, il trattamento chirurgico per l'incontinenza da urgenza è la cistoplastica per ampliamento, nella quale si aumenta la capacità della vescica in modo tale che le contrazioni vescicali durante la fase di riempimento non determinino una perdita di urina. La cistoplastica può richiedere o l'incorporamento di una porzione di intestino nella vescica (una procedura nota come enterocistoplastica) o l'asportazione di una larga porzione del muscolo detrusore preservando la mucosa sottostante per consentire lo sviluppo di un diverticolo (una procedura nota $\mathrm{CO}^{-}$ me autoampliamento) [55]. Sebbene l'enterocistoplastica sia efficace, esistono complicazioni che possono comprendere uno svuotamento inadeguato, la ritenzione di muco e uno squilibrio elettrolitico. L'autoampliamento evita la morbidità post operatoria che 
Figure $4 \boldsymbol{a}$ - Costs of urinary incontinence in 1995 [56].

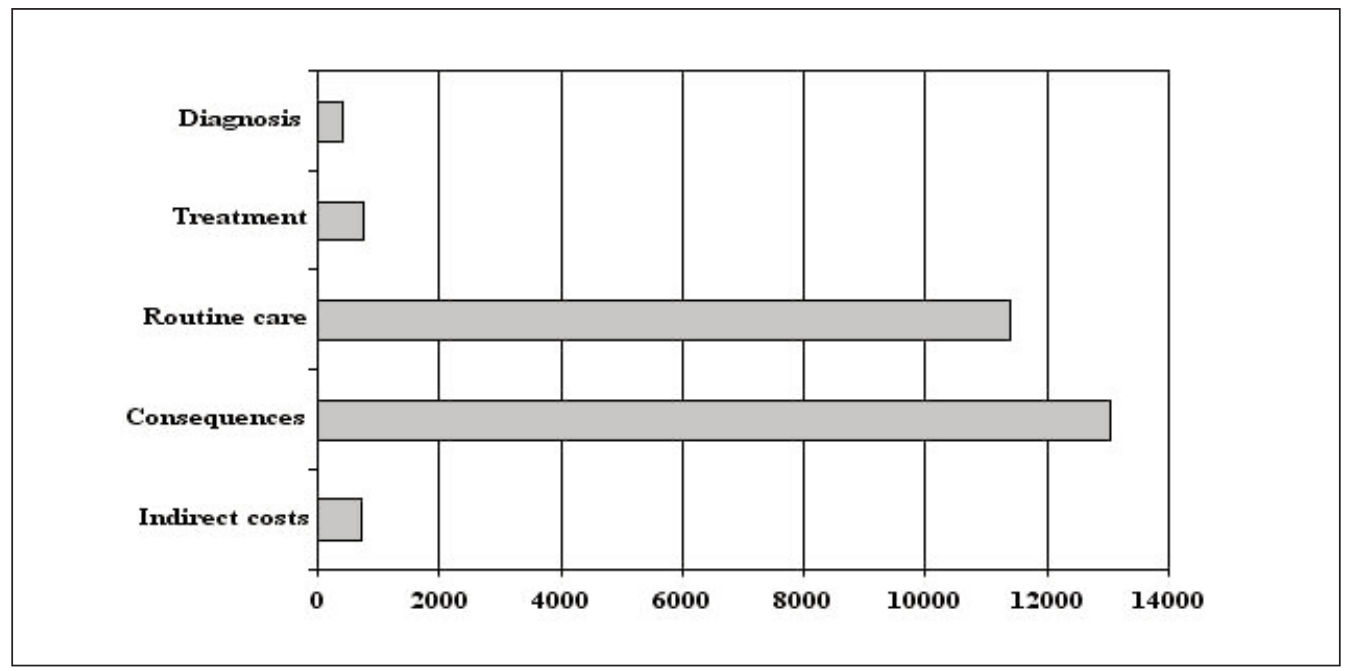

\section{COSTS OF MANAGING URINARY INCONTINENCE}

The costs associated with urinary incontinence and $\mathrm{OAB}$ are high. For example, it is estimated that $\$ 1.1$ billion is spent each year in the USA on disposable pads for adults [28]. In addition, there may be difficulties in obtaining reimbursement for certain behavioural therapies. A 1995 study of the economic impact of incontinence in individuals aged 65 years of age and older in the USA estimated the societal cost to be $\$ 26.3$ billion, or $\$ 3565$ per patient [56]. The direct costs alone, including diagnostic and treatment costs, routine care, and consequence costs, were estimated to represent $\$ 25.6$ billion of the total costs - greatly exceeding the $\$ 14$ bil- può svilupparsi in seguito alla enterocistoplastica, ma non viene considerata altrettanto efficace [9].

\section{COSTI DI GESTIONE DELL'INCONTINENZA URINARIA}

I costi associati all'incontinenza urinaria e al fenomeno di OAB sono alti. Le stime riportano, ad esempio, che ogni anno, negli Stati Uniti d'America, si spende \$1.1 miliardo per tamponi non riutilizzabili per agli adulti [28]. In aggiunta, possono verificarsi alcune difficoltà nell'ottenere il rimborso per alcune terapie comportamentali. Uno studio condotto nel 1995 sull'impatto economico dell'incontinenza nei soggetti di 65 anni di età ed oltre in soggetti più anziani, negli Stati Uniti d'America, ha stimato che il costo sociale si aggira sui $\$ 26.3$ miliardi, o sui $\$ 3565$ per paziente [56]. Solo i costi diretti, inclusi i costi di diagnosi e trattamento, le cure di routine e i costi delle conse- 
Figure $4 \mathbf{b}$ - Distribution of treatment costs [56].
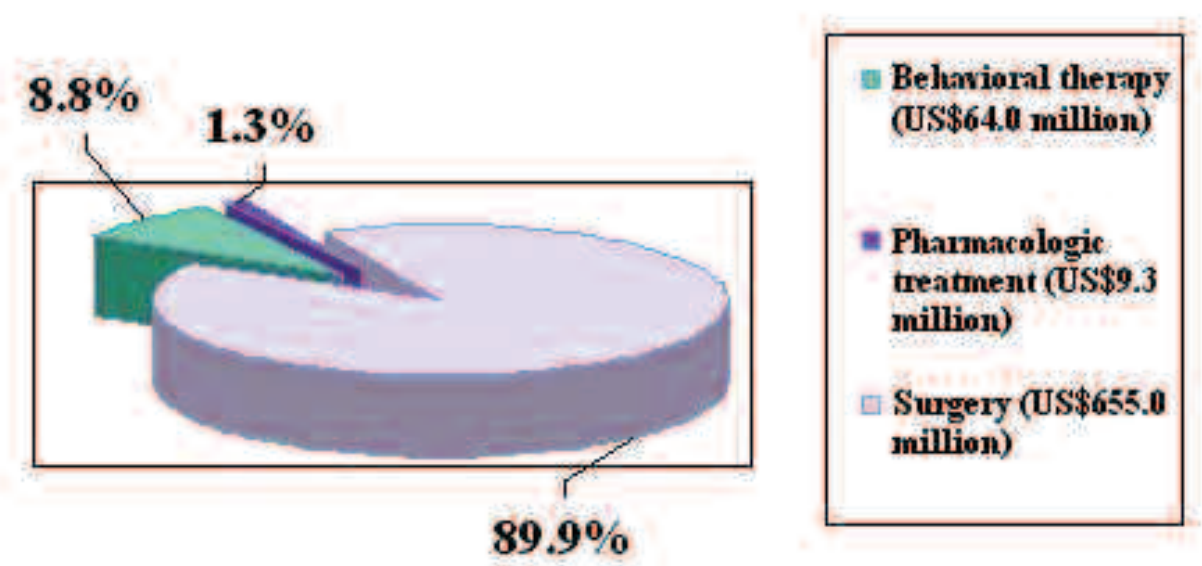

lion in direct medical costs spent on treatment of osteoporosis, for example [57]. The cost of care for urinary incontinence and $\mathrm{OAB}$ is rising; estimates have increased from $\$ 8.2$ billion in 1984 to $\$ 16.4$ billion in 1993 to the current published estimate of $\$ 26.3$ billion. This observed increase may be partly attributed to the aging population, but also in the number of comorbid events associated with under-treatment. In the NOBLE Program, a cost-of-illness analysis is also under way to identify the OAB-specific burden, in addition to the costs associated with UI.

The direct costs associated with urinary incontinence include the costs of diagnosis and of treatment, including behavioral techniques, pharmacotherapy and surgery, as well as costs arising from management of the consequences of urinary incontinence, such as skin irritation, urinary guenze, sono stati stimati in $\$ 25.6 \mathrm{mi}-$ liardi dei costi totali - superando di gran lunga i \$14 miliardi in costi medici diretti spesi nel trattamento delle osteoporosi, ad esempio [57]. Il costo della cura nei casi di incontinenza urinaria o di $O A B$ è in crescita; le stime sono aumentate da $\$ 8.2$ miliardi nel 1984 ai \$16.4 miliardi nel 1993, fino alla stima recentemente pubblicata che si attesta a \$26.3 miliardi. Questo aumento riconosciuto può essere in parte attribuito all'invecchiamento della popolazione. Anche nel Programma NOBLE, un'analisi dei costi della malattia è in fase di sviluppo per l'identificazione dell'onere specifico per l'OAB, in aggiunta ai costi associati all'incontinenza urinaria (UI).

I costi diretti associati all'IU comprendono i costi della diagnosi e del trattamento, incluse le tecniche comportamentali, la terapia farmacologica e la chirurgia come pure i costi deri- 
Figure 4c - Distribution of consequences costs [56].

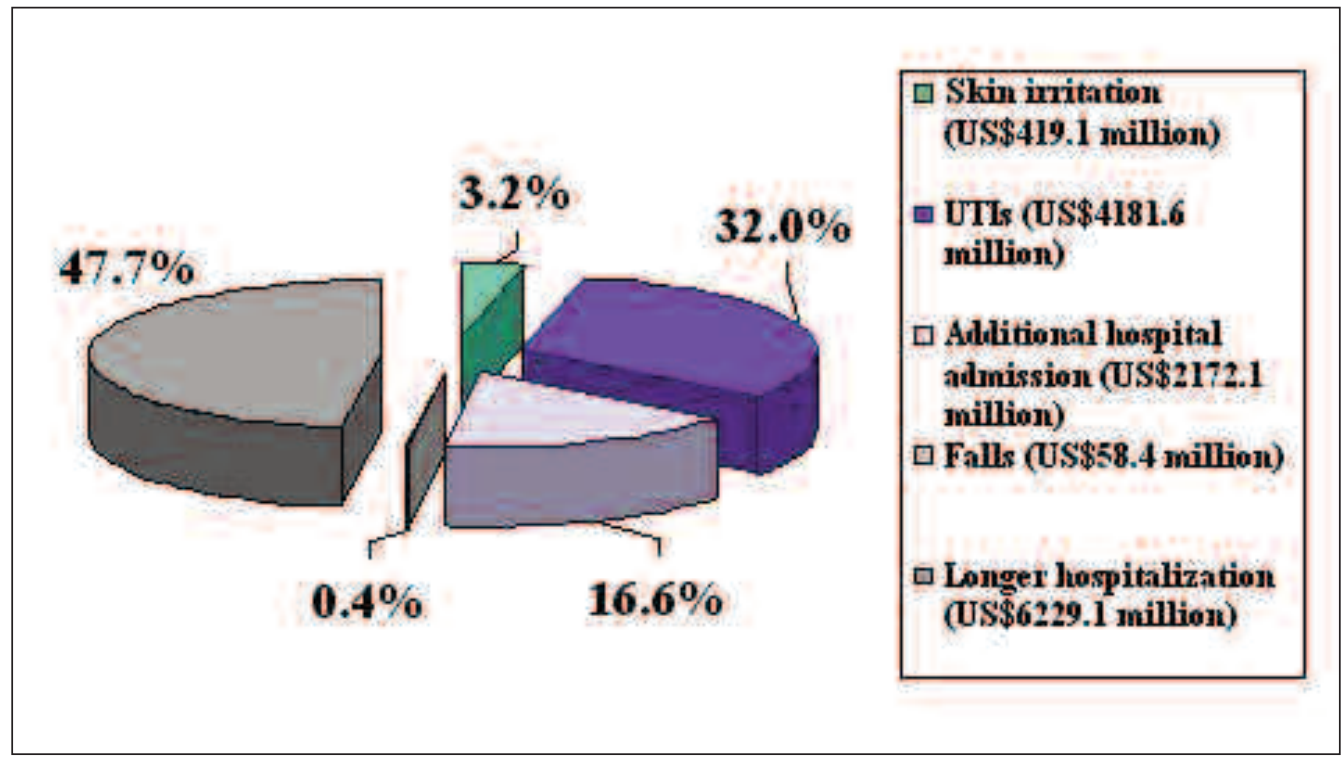

tract infections and falls as a result of patients rushing to reach the toilet [56]. The indirect costs include costs associated with home care, such as loss of earnings by either the patient or her partner, and laundry costs as a result of incontinence episodes.

As Wagner and $\mathrm{Hu}$ point out, the figure of $\$ 26.3$ billion annually is almost certainly an underestimate of the true costs of urinary incontinence in the USA, as it does not include costs for patients under 65 years of age [56]. While the costs of diagnosis and treatment among such patients would be unlikely to differ from those of older patients, they might be expected to have higher indirect costs due to loss of earnings. Indeed, based on an estimated prevalence of 14 million, Hu and Wagner calculated that the total costs of urinary incontinence could be as high as $\$ 46$ billion annually [56]. vanti dalla gestione delle conseguenze dell'incontinenza urinaria, come irritazione della pelle, infezioni del tratto urinario e cadute che si verificano come risultato della fretta nel raggiungere la toilette [56]. I costi indiretti includono i costi associati alla gestione domestica, come ad esempio la perdita di guadagni sia da parte del paziente che da quella del partner, e i costi della lavanderia come risultato di episodi di incontinenza.

Come hanno evidenziato Wagner e $\mathrm{Hu}$, la cifra di \$26.3 miliardi annuale è quasi certamente una sottostima dei costi reali dell'incontinenza urinaria negli USA, poiché non si tiene conto dei costi per i pazienti al di sotto dei 65 anni di età [56]. Mentre è improbabile che i costi della diagnosi e del trattamento in questi pazienti differiscano da quelli indicati per i pazienti più anziani, è possibile aspettarsi che $\mathrm{i}$ costi indiretti siano superiori a causa 


\section{CONCLUSION}

Urinary incontinence and $\mathrm{OAB}$ continue to be 'silent diseases' and have been referred to as "one of the last social taboos" [23]. They are associated with considerable economic impact and significant reductions in HRQOL.

Urinary incontinence is estimated to affect approximately 13 million people in the USA, and is seen more commonly in women than in men. However, variability between studies in the population investigated and in the definition of urinary incontinence has made it difficult to obtain accurate estimates of the prevalence of urinary incontinence in women. Furthermore, many epidemiological studies have focused only on urine loss without consideration of symptoms of urinary frequency and urgency. Consequently the true prevalence of the symptoms of frequency and urgency with or without urge incontinence (OAB) is unknown, although is estimated to be at least 17 million people in the USA.

Little is known about the natural history of incontinence or OAB. There is evidence of remission in some patients (i.e. previously incontinent patients become continent over time), although the estimated remission rates vary widely [58-60]. Clearly, this is an area for further study. It is hoped that della perdita di guadagni. Infatti, in base a una diffusione stimata di 14 milioni di dollari, Hu e Wagner hanno calcolato che i costi totali dell'incontinenza urinaria potrebbero aggirarsi sui $\$ 46$ miliardi annuali [56].

\section{CONCLUSIONE}

L'incontinenza urinaria e il fenomeno di OAB continuano ad essere "malattie silenziose" a cui è stato fatto riferimento come "uno degli ultimi taboo sociali" [23]. Esse vengono associate a un impatto economico considerevole e a una riduzione significativa nella HRQoL.

Si stima che l'IU affligga circa 13 milioni di persone negli USA e si verifichi più frequentemente nelle donne piuttosto che negli uomini. Tuttavia la variabilità tra gli studi effettuati nella popolazione analizzata e nella definizione di incontinenza urinaria ha reso difficile ottenere stime accurate della diffusione dell'incontinenza urinaria nelle donne. Inoltre, numerosi studi epidemiologici si sono concentrati soltanto sulla perdita di urina tralasciando i sintomi di urgenza e frequenza urinaria. Di conseguenza la reale diffusione dei sintomi di frequenza e urgenza associati o meno all'incontinenza da urgenza (OAB) è sconosciuta, sebbene si stima che sia almeno pari a 17 milioni di persone negli Stati Uniti d'America.

La conoscenza dell'evolversi naturale dell'incontinenza o dell'OAB è scarsa. Esistono testimonianze di regressione in alcuni pazienti (i.e. pazienti precedentemente incontinenti sono diventati continenti col tempo), sebbene i tassi di regressione stimati variano ampiamente [58-60]. Chiaramente si tratta 
the NOBLE (National Overactive BLadder Evaluation) Program will provide a more accurate picture of the prevalence, impact, burden and natural history of $\mathrm{OAB}$ in the USA.

A range of effective treatments are available for the patient with urinary incontinence or OAB. Behavioral techniques, such as Kegel exercises for urinary incontinence and bladder retraining techniques for urge incontinence and $\mathrm{OAB}$ are effective in reducing incontinence episodes in many patients. Surgery is effective in up to $90 \%$ of women with stress incontinence and the Sling and Burch colposuspension are the most popular. Pharmacotherapy, particularly treatment with anticholinergic agents, is used for the treatment of urge incontinence and OAB. The antimuscarinic agent oxybutynin is associated with a high incidence of adverse effects, particularly dry mouth. Tolterodine, a new antimuscarinic agent that has been developed specifically for the treatment of $\mathrm{OAB}$, is as effective as oxybutynin but has a superior tolerability profile and is the most commonly used agent [47].

Finally, education of both healthcare professionals and the public is the key to the optimal management of urinary incontinence. Public education is required to remove the stigma surrounding urinary incontinence and to empower patients and their families to obtain the most appropriate treatment and support. Classification of $\mathrm{OAB}$ as a disease will raise the profile of bladder symptoms among healthcare professionals and encourage them to maintain clinical suspicion, and to correctly diagnose di un'area che necessita di studi ulteriori. Si spera che il Programma NOBLE (National Overactive Bladder Evaluation) possa fornire un quadro più accurato della diffusione, dell'impatto, del peso e dell'evolversi naturale dell'OAB negli Stati Uniti d'America.

Sono disponibili una serie di trattamenti efficaci per i pazienti che soffrono di incontinenza urinaria o di OAB. Le tecniche comportamentali, come ad esempio gli esercizi di Kegel per l'incontinenza urinaria e le tecniche di training della vescica per l'incontinenza da urgenza e per OAB sono efficaci nel ridurre gli episodi di incontinenza in molti pazienti. La chirurgia è efficace nel 90\% delle donne che soffrono di incontinenza da stress e la procedura di Sling e la colposospensione di Burch sono le procedure più conosciute. La terapia farmacologica, in particolare il trattamento con agenti anticolinergici, viene utilizzata per il trattamento dell'incontinenza da urgenza e per l'OAB. L'agente antimuscarinico ossibutinina viene associato a una larga incidenza di effetti collaterali, in particolare quello della secchezza delle fauci. La tolterodina, un agente antimuscarinico sviluppato specificatamente per il trattamento dell'OAB, risulta tanto efficace quanto l'ossibutinina ma possiede un profilo superiore di tollerabilità e per tale ragione è l'agente utilizzato più comunemente [47].

In ultimo, l'istruzione sia dei professionisti della salute che del pubblico rappresenta la chiave per la gestione ottimale dell'incontinenza urinaria. L'istruzione pubblica è necessaria per eliminare lo stigma che circonda l'incontinenza urinaria e per mettere in grado i pazienti e i loro familiari di ottenere il 
and manage cases in a timely manner. supporto e il trattamento più appropriati. La classificazione di OAB come malattia aumenterà il profilo dei sintomi relativi alla vescica tra i professionisti della salute e li incoraggerà a mantenere una soglia di allerta a livello clinico e a diagnosticare e gestire correttamente i casi.

Address for correspondence:

Dr Eboo Versi

11 Sheephill Drive

Gladstone

NJ 07934

USA 


\section{REFERENCES}

1 - HAMPEL C., WIENHOLD D., BENKEN N., EGGERSMANN C., THUROFF J. : Definition of overactive bladder and epidemiology of urinary incontinence. Urology. 1997;50(6A):4-17.

2 - HUNSKAAR S., ARNOLD E., BURGIO K., DIOKNO A., HERZOG A., MALLETT V., eds. :

Epidemiology and natural bistory of urinary incontinence.

Monaco: Health Publications Ltd; 1998.

3 - ABRAMS P., WEIN A.:

The overactive bladder: A widespread and treatable condition. Sparre Medical Group; 1998.

4 - BURGIO K., MATTHEWS K., ENGEL B. :

Prevalence, incidence and correlates of urinary incontinence in bealthy, middle-aged women.

J Urology. 1991;146:1255-1259.

5 - MASON L., GLENN S., WALTON I., APPLETON C. : The prevalence of stress incontinence during pregnancy and following delivery. Midwifery. 1999;15(2):120-128.

6 - DIOKNO A., BROCK B., BROWN M., HERZOG A. :

Prevalence of urinary incontinence and other urological symptoms in the noninstitutionalized elderly.

J Urology. 1986;136:1022-1025.

7 - OUSLANDER J., KANE R., ABRASS I. :

Urinary incontinence in elderly nursing bome patients. JAMA. 1982;248:1194-1198.

8 - Palmer M., German P., Ouslander J. : Risk factors for urinary incontinence one year after nursing bome admission. Res Nurs Health. 1991;14:405-412.

9 - WEIN A. : The overactive bladder: an overview for primary bealth care providers. Int J Fertil Womens Med. 1999;44:56-66.

10 - THOM D. : Overactive bladder: epidemiology and impact on quality of life. Patient Care. 2000;suppl:6-14.

11 - ABRAMS P., COYNE K., SCHMIER J. : Health-related quality of life in continent $O A B$ subjects: early results from the NOBLE Program (Poster).

ICS Annual Meeting. Tampere, Finland; 2000.

12. STEWART W., HERZOG R., LIBERMAN J., PAYNE C. : Variation in prevalence of $O A B$ symptoms in population sample: early results from the NOBLE Program (Poster).

AUGS Annual Meeting; 2000. 
13 - NYGAARD I., LEMKE J. :

Urinary incontinence in rural older women: prevalence, incidence and remission. JAGS. 1996;44:1049-1054.

14 - DAY P. :

Findings of a three-year retrospective study to investigate prevalence and

incidence of urinary incontinence and $O A B$ in a typical managed care setting. Pharm Pract Manage Q. 2000:1-11.

15 - JACKSON S. :

The patient with an overactive bladder-symptoms and quality-of-life issues. Urology. 1997;50(supplement 6A):18-24.

16 - KOBELT G. :

Economic considerations and outcome measurement in urge incontinence. Urology. 1997;51(supplement 6A):100-107.

17 - BROWN J. :

Urge incontinence: the patient's perspective.

J Womens Health. 1998;7:1263-1269.

18 - LENDERKING W., NACKLEY J. :

A review of the quality of life aspects of urinary urge incontinence.

Pharmacoeconomics. 1996;9:11-23.

19 - KOBELT-NGUYEN G. :

Correlations between symptoms of urge incontinence and scores of a generic quality of life instrument (SF-36) and bealth status measurements (EuroQol) and between changes in symptoms and QoL Scores [abstract].

27th ICS meeting. Japan; 1997.

20 - LIBERMAN J., HUNT T., STEWART W., et al. :

Health-related quality of life among individuals with symptoms of overactive bladder: results from the United States National Overactive Bladder Survey. Urology. 2001; In press.

21 - COYNE K., SCHMIER J., HUNT T., COREY R., LIBERMAN J., REVICKI D. : Developing a specific HRQL instrument for overactive bladder (Abstract). ISPOR 2000. Arlington, USA; 2000.

22 - ROBERTS R., JACOBSEN S., RHODES T., et al. : Urinary incontinence in a community-based cobort: prevalence and bealthcare-seeking. JAGS. 1998;46:467-472.

23 - MORRIS K. :

Tackling the taboo of urinary incontinence.

Lancet. 1999;353:128.

24 - DIOKNO A. :

Epidemiology and psychosocial aspects of incontinence.

Urol Clin North Am. 1995;22:481-485.

25 - FIERS S. :

Breaking the cycle: the etiology of incontinence dermatitis and evaluating and using skin care products. Ostomy Wound Manage. 1996;42(3):32-40. 
26 - ICS. Incontinence Knowledge Centre Website: International Continence Society; 2000.

27 - WYMAN J., HARKINS S., CHOI S., TAYLOR J., FANTL J. : Psychosocial impact of urinary incontinence in women. Obstet Gynecol. 1987;70(3):378-381.

28 - AHCPR. Urinary incontinence in adults: acute and chronic management. Clinical Practice Guideline Number 2; 1996.

29 - COLLING J., NEWMAN D., McCORMACK K., PEARSON B. : Behavioural management strategies for urinary incontinence. J ET Nurs. 1993;20:9-13.

30 - CASTLEDEAN C., DIUFFIN H., ASHER M., YEOMANSON C. : Factors influencing outcome in elderly patients with urinary incontinence and detrusor instability. Age Ageing. 1985;14:303-307.

31 - BURNS P., PRANIKOFF K., NOCHAJSKI T., DESOTELLE P., HARWOOD M. : Treatment of stress incontinence with pelvic floor excercises and biofeedback.

JAGS. 1990;38:341-344.

32 - FREWEN W. :

Role of bladder training in the treatment of the unstable bladder in the female.

Urol Clin North Am. 1979;6:273-277.

33 - DIOKNO A. :

Preference, compliance and initial outcome of therapeutic options chosen by female patients with urinary incontinence.

J Urology. 1995;154(5):1727-1730.

34 - SULLIVAN J., ABRAMS P. :

Pharmacological management of incontinence.

Eur Urol. 1999;36(Suppl 1):89-95.

35 - MOLD JW. :

Pharmacotherapy of urinary incontinence.

Am Fam Physician. 1996;54(2):673-685.

36 - CARDOZO L., KELLEHER C. :

Sex hormones, the menopause and urinary problems.

Gynaecological Endocrinology. 1995;9:75-84.

37 - YARKER Y., GOA K., FITTON A. :

Oxybutynin. A review of its pharmacodynamic and pharmacokinetic

properties, and its therapeutic use in detrusor instability.

Drugs Aging. 1995;6:243-262.

38 - DESAGNE A., LELORIER J. :

Incontinence drug utilization patterns in Quebec, Canada.

Value in Health. 1999;2(6):452-458. 
39 - KATZ I., SANDS L., BILKER W., DiFILIPPO S., BOYCE A., D’ANGELO K. : Identification of medications that cause cognitive impairment in older people: the case of oxybutynin chloride.

JAGS. 1998;46:8-13.

40 - BEERS H. :

Explicit criteria for determining potentially inappropriate medication use by the elderly.

Arch Intern Med. 1997;157.

41 - VERSI E., APPELL R., MOBLEY D., PATTON W., SALTZSTEIN D. :

Dry mouth with conventional and controlled-release oxybutynin in urinary incontinence. The Ditropan XL Study Group.

Obstet Gynecol. 2000;95(5):718-721.

42 - NILVEBRANT L., HALLEN B., LARSSON G. :

Tolterodine - a new bladder selective muscarinic receptor antagonist: preclinical pharmacological and clinical data.

Life Science. 1997;60:1129-1136.

43 - APPELL R. :

Clinical efficacy and safety of tolterodine in the treatment of overactive

bladder: a pooled analysis.

Urology. 1997;50(supplement 6A):90-99.

44 - ABRAMS P., FREEMAN R., ANDERSTROM C., MATTIASSON A. :

Tolterodine, a new antimuscarinic agent: as effective but better tolerated than oxybutynin in patients with an overactive bladder.

Br J Urol. 1998;81:801-810.

45 - CHANCEllor M., FREEDMAN S., MiTCHESON H., ANTOCI J., PRIMUS G., WEIN A. :

Tolterodine, an effective and well tolerated treatment for urge incontinence and other overactive bladder symptoms.

Clin Drug Invest. 2000;19:83-91.

46 - VAN KERREBROECK P. :

Significant decreases in perception of urgency and urge incontinence episodes with once-daily tolterodine treatment in patients with overactive bladder (Abstract).

ICS Annual Meeting. Tampere, Finland; 2000.

47 - IMS. National Prescription Data. 2000;Nov.

48 - SCHMIDT R.A., D-H Z., DOGGWEILER R. :

Urinary incontinence update: old traditions and new concepts.

Advance in Internal Medicine. Vol. 44: Mosby Inc; 1999:19-57.

49 - GLAZENER C., COOPER K. :

Anterior vaginal repair for urinary incontinence in women.

Cochrane Database Syst Rev. 2000;3:CD001755.

50 - JARVIS G. :

Surgery for genuine stress incontinence.

Br J Obstet Gynaecol. 1994;101:371-374. 
51 - BURTON G. :

A three-year prospective randomised urodynamic study comparing open and laparoscopic colposuspension (Abstract).

Neurourol Urodyn. 1997;16:353-354.

52 - SU T., J.P., WANG Y., YANG J., WEI H., HUANG C. :

Is modified in situ vaginal wall sling operation the treatment of choice for recurrent genuine stress incontinence?

J Urol. 1999;162(6):2073-2077.

53 - WARD K., HILTON P., BROWNING J. :

Changes in quality of life following surgery with tension free vaginal tape (TVT) or colposuspension for primary genuine stress incontinence (Abstract). ICS Annual Meeting. Tampere, Finland; 2000.

54 - JANKNEGT R., VAN KERREBROECK J., LYCKLAMA A. : Sacral nerve modulation for urge incontinence.

J Urology. 1997;157:317-320.

55 - APPELL R. :

Surgery for the treatment of overactive bladder.

Urology. 1998;51(2A):27-29.

56 - WAGNER T., HU T. :

Economic costs of urinary incontinence in 1995.

Urology. 1998;51(3):355-361.

57 - NATIONAL OSTEOPOROSIS FOUNDATION.

Osteoporosis: Fast Facts 1999

Washington, DC: National Osteoporosis Foundation; 2000.

58. HERZOG A., FULTZ N. :

Prevalence and incidence of urinary incontinence in community-dwelling populations.

J Am Geriatr Soc. 1990;38:273.

59. YARNELL J., ST LEGER A. :

The prevelance, severity and factors associated with urinary incontinence in a random sample of the elderly.

Age Aging. 1979;8:81-85.

60 - THOMAS T., PLYMAT K., BLANNIN J., MEADE T. :

Prevalence of urinary incontinence.

BMJ. 1980;281:1243-1245. 